\title{
SELECTING A LOCATION FOR A LIQUEFIED NATURAL GAS TERMINAL IN THE EASTERN BALTIC SEA
}

\author{
Vygantas Bagočius ${ }^{1,2}$, Edmundas Kazimieras Zavadskas ${ }^{3}$, Zenonas Turskis ${ }^{4}$ \\ 1,3,4 Dept of Construction Technology and Management, \\ Vilnius Gediminas Technical University, Lithuania \\ ${ }^{2}$ Dept of Civil Engineering Department, Klaipeda University, Lithuania
}

Submitted 28 December 2012; accepted 18 October 2013

\begin{abstract}
Liquefied Natural Gas (LNG) industry is among the fastest growing energy market sectors. The gas terminal in Klaipeda allows Lithuania to import natural gas from various countries around the world. One of the most debatable subjects is the location of the future terminal. The problem pertaining to selection of construction sites for the LNG terminal should be investigated and solved using the set of multiple conflicting criteria. Many researchers argue that similar problems should be solved by applying several different Multi-Criteria Decision-Making (MCDM) methods. The research presents the model for application of three different MCDM methods and aggregation of solution results for the problem, which is based both on different objective data and on investigation of expert opinions for determining subjective criteria weights for the problem.
\end{abstract}

Keywords: liquefied natural gas, terminal, MCDM, SAW, TOPSIS, COPRAS, seaport.

Reference to this paper should be made as follows: Bagočius, V.; Zavadskas, E. K.; Turskis, Z. 2014. Selecting a location for a liquefied natural gas terminal in the Eastern Baltic Sea, Transport 29(1): 69-74.

http://dx.doi.org/10.3846/16484142.2014.897996

\section{Introduction}

Energy security and diversification of energy sources is among the most challenging tasks of all countries. Mainly due to historical reasons, Lithuania found itself in a situation, where natural gas is supplied by a single supplier only - the Russian JSC 'Gazprom' (Sweco Lietuva 2011).

A similar situation has developed not only in the sector of natural gas. Attempts to become an energyindependent state are impeded by a number of obstacles: high rate of dependence on gas and power import, no integration into EU networks, low efficiency of energy use, dominance of monopolies in the energy systems together with a lack of a developmental vision for the energy infrastructure (Augutis et al. 2013).

Energy security is one of prevalent objects under a discussion currently spreading around the world, which not only allows to be successful in developing national economic prosperity, but also to influence social development of the countries (Jakštas 2010).

It is worth mentioning that a part of natural gas in the initial energy balance, despite few exceptions, has a tendency to increase. The highest rates of use in respect to natural gas in Lithuania were reached in 1991 with a number of $6 \cdot 10^{6} \mathrm{Nm}^{3}$ (Sweco Lietuva 2012). Unfortunately in Lithuania, gas use had a tendency to noticeably reduce with years. However, having closed Ignalina Nuclear Power Plant in 2009, the demand for natural gas has noticeably increased. It is anticipated that gas demand in the year of 2020 might range from $1.6 \cdot 10^{6} \mathrm{Nm}^{3}$ to $3.7 \cdot 10^{6} \mathrm{Nm}^{3}$.

There is no doubt that emergence of alternative sources for gas supply is the only practical measure, which might ensure a decrease in the gas price and break ties with the only supplier. Import terminals for Liquefied Natural Gas (LNG) could work as one of alternative ways for gas supply (Sweco Lietuva 2012).

LNG terminal is a marine terminal designed for export and import of LNG using special gas carriers. Such terminals may be offshore and onshore. Tankers approach the offshore or onshore terminal and transfer LNG, which then is converted into natural gas of a usual state and supplied to consumers via the installed pipelines. LNG is odourless, colourless, nontoxic, noncor-

Corresponding author: Edmundas Kazimieras Zavadskas

E-mail: edmundas.zavadskas@vgtu.lt 


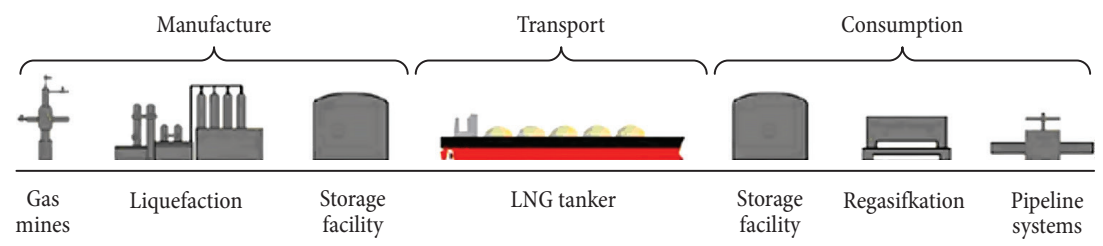

Fig. 1. LNG supply chain (NatGas.info 2013)

rosive natural gas consisting almost entirely of methane $\left(\mathrm{CH}_{4}\right) . \mathrm{LNG}$ is kept at $-161{ }^{\circ} \mathrm{C}$ at a pressure similar to atmospheric (Tarvydas, Gatautis 2006).

The first ever offshore LNG terminal relies on a concrete Gravity Based Structure (GBS) which has been installed successfully $15 \mathrm{~km}$ off the Italian coast in September 2008. After commissioning the majority of systems in dock, the terminal was towed over $3000 \mathrm{~km}$ to the Adriatic Sea and ballasted with approx. $250000 \mathrm{t}$ of sand to secure its safe foundation (Ludescher et al. 2011).

Today, the LNG market is in a constant growth with LNG becoming a valuable alternative for oil and gas, which are supplied via the pipelines from their place of extraction (Sweco Lietuva 2012).

LNG infrastructure is composed of two, usually very remotely related fields - production and consumption, which are connected by LNG carrying tankers, referred to as virtual conveyors (Fig. 1).

Currently, the largest Europe's LNG import terminal South Hook is operating in the United Kingdom. Its annual capacity reaches $18 \cdot 10^{6} \mathrm{Nm}^{3}$ (South Hook LNG... 2013). Having expanded the Gate import terminal, operating in Holland, its annual capacity would increase up to $22 \cdot 10^{6} \mathrm{Nm}^{3}$ and would become the largest in Europe (LNG terminal at... 2013).

Sweden's terminal in Nynäshamn is the first LNG terminal in the Baltic Sea region. It was officially opened on 27 May 2011 (Sweden's First LNG... 2013).

The construction consists of sheet piling at the centre of a bank, which is constructed to be suitable for vehicular traffic. In addition to the infrastructure for handling ships, the breakwater includes a complex pipe system, which is used to convey the liquid gas (Ludescher et al. 2011).

An interdepartmental work group initiated the analysis of two technological alternatives for the LNG terminal - onshore and offshore. The workgroup has established that the most appropriate technologic solution is an offshore terminal (Tarpžinybinès darbo... 2010).

Selection of a location for the construction site is complex and multi-criteria decision-making problem.

\section{LNG terminal in Klaipèda}

Due to the geographical location of Lithuania followed by the historic situation, the single alternative and independent route for the gas import is the shore of the Baltic Sea. The share of gas imported via seaport terminals using liquefied gas technology has been rapidly growing around the world. Unlike the overland gas transfer technology, the natural gas is transported in its liquefied state in special carriers from a place of extraction to the designated import terminal, where it is converted into the gaseous state and supplied via the pipelines (Sweco Lietuva 2011).

The project of the LNG terminal is comprised of the LNG terminal, related infrastructure and the gas pipeline, which should be built to connect the LNG terminal with the Lithuanian gas pipeline system. Acknowledgement of the LNGs terminal as a project of state significance, grants a possibility to apply special terms and conditions for investments and business (Sweco Lietuva 2011). Principle advantages of LNG (Sweco Lietuva 2012):

- eliminates dependence of Lithuania on the sole external gas supplier;

- creates conditions enabling Lithuania to independently obtain natural gas to cover emergency gas demand;

- creates a possibility for Lithuania to access gas spot markets;

- further developmental costs of the terminal are relatively low;

- balances supply and demand during summer/ winter seasons;

- grants a larger gas storage besides the tanks at the terminal.

During the process of planning of the LNG terminal, it is highly important to consider several distinct parameters that have an influence on the terminal's functioning, economy and rationality. Principal parameters of the LNG terminal (SAIC... 2010) are: size, place of installation and technology.

During the planning procedure for the LNG terminal expansion, the following technical (engineering) solutions are considered (Sweco Lietuva 2011):

- anticipated annual capacity of $2 \cdot 10^{6} \div 3 \cdot 10^{6} \mathrm{Nm}^{3}$ of natural gas, $7 \cdot 10^{6} \mathrm{Nm}^{3}$ per 24 hours; The in-

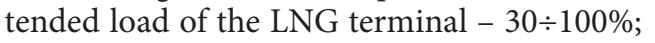

- anticipated nominal capacity of gasification unit $230000 \mathrm{Nm}^{3} / \mathrm{h}$, maximum $-460000 \mathrm{Nm}^{3} / \mathrm{h}$, pressure to the system $-60 \mathrm{~kg} / \mathrm{cm}^{2}$;

- anticipated size of the LNG terminal: $130000 \div 185000 \mathrm{~m}^{3}$, length - up to 300 meters, width - up to 50 meters, draught - up to 12.5 meters;

- size of anticipated LNG carriers to be accepted up to $140000 \mathrm{Nm}^{3}$;

- anticipated maximum capacity of a pump, through which LNG will be pumped out from the LNG carrier into the LNG terminal is $12000 \mathrm{~m}^{3} / \mathrm{h}$ (under such speed LNG carrier would be emptied in $10 \div 15$ hours). 
Having considered recommendations it was decided to build an offshore terminal. Gravity Based Structure (GBS) is installed in consideration of place specific parameters and most often adjusted based on a dominating wind and wave course. Usually with GBS, the LNG terminal is built as well (Foss 2006).

\section{Master Data:}

Following the report presented by the interdepartmental workgroup, three principal locations for the LNG terminal are considered (Fig. 2) (Sweco Lietuva 2011):

- alternative (I) of the Kiaules Nugara island;

- alternative (II) of Melnrage;

- alternative (III) of Butingè.

A comparative multi-criteria analysis on location alternatives for the LNG terminal will consider social, environmental, economic and technological factors.

In order to proceed with the successful application of multi-criteria analysis, it is essential on one hand to determine and examine an adequate number of criteria that will give a representative and complete picture of alternative scenarios that are investigated and on the other hand to calibrate the criteria that will be examined according to their characteristics (Rousis et al. 2008).

Fifteen individual criteria were selected in total and categorized into four groups (S, A, E and T) of criteria, as described below (Sweco Lietuva 2011).

\section{Group of Social Criteria (S):}

S1. International relations - consequences related to implementation of the plan to be realized in the Republic of Lithuania might have an impact on the environment of other European Union member states; this might necessitate submission of the draft plan and a respective assessment report prior to acceptance and (or) approval of the above named plan. Such cross-country consultations take time and might extend the implementation period of the project.

S2. Civil safety - LNG systems have been extensively operating for more than 40 years without any major accidents except some during the first years of use. However, high risk potential with a source of concentrated power cannot be negated even though the analysis of statistical information demonstrates that a chance of such risk is not high. Risk is assessed and expressed in the ratio of a potential danger and probability of its realization.

S3. Psycho-emotional background - it is very logical that plans to build the LNG terminal next to a densely populated territory might raise concerns among local residents.

\section{Group of Environmental Criteria (A):}

A1. Landscape - prior to implementation of the LNG terminal project and its related infrastructure, it is necessary to conduct a field research, analysing the potential impact on the landscape and the necessity to change provisions of applicable legal acts: Comprehensive Plan of the Territory of the Republic of Lithuania (Lietuvos Respublikos teritorijos... 2002) and Special Plan for Lithuanian Coastal Strip Management (Pajūrio žemyninès dallies... 2011).

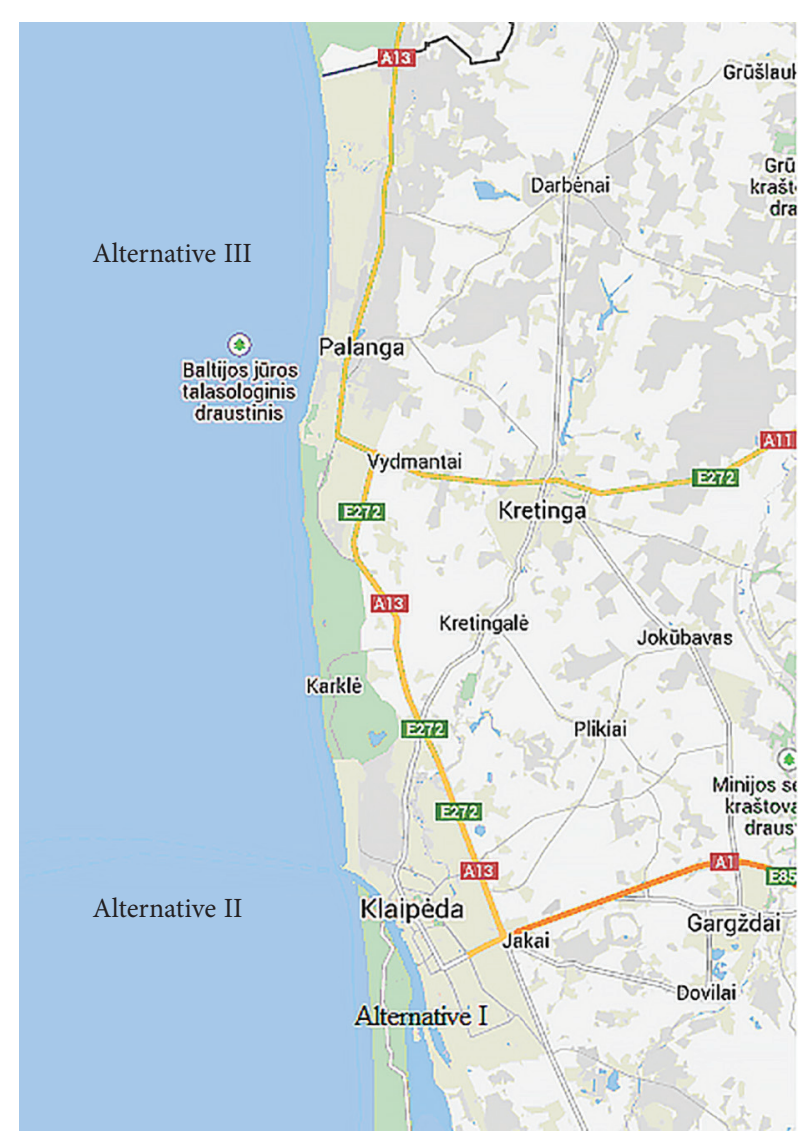

Fig. 2. Potential locations for the LNG terminal

A2. Cultural heritage - during the process of design of the high-pressure gas pipeline, the use of potentially valuable territories considered as a cultural heritage should be taken into consideration.

A3. Biological diversity - one of the most significant factors that cause a divergent assessment of alternatives is the construction of high-pressure pipelines. Preference could be given to solutions that have the least impact and reduced or completely eliminated (avoiding valuable territories) possible negative effects on significant territories or species.

A4. Environmental air - the greatest air pollution threat is possible during regasification of LNG as such process requires high capacity (approximately $70 \mathrm{MW}$ ). In absence of necessary power or in case of other alternatives, where supply of such heat capacity is not possible from the land due to absence of suitable infrastructure established onshore, it would be generated locally by burning available LNG $(2 \div 2.5 \%$ of reloaded gas quantity).

A5. Noise - during the course of operation of the LNG terminal, the source of noise might be the engines, pumps or compressors of a ship, by which gas is supplied to shore.

\section{Group of Economic Criteria (E):}

E1. Impact on Klaipeda Seaport expansion - in general, the impact on Klaipeda Seaport would be related to limitation of navigation inside the seaport, i.e. 
during the time a LNG carrier would enter or depart from the seaport, navigation would most probably be impossible (for the sake of safety).

E2. Land use - irrespective of the alternative, it will be necessary to build a gas pipeline from the LNG terminal to the main system that belongs to JSC 'Lietuvos dujos'.

E3. Construction costs - price for construction of LNG terminal is specified in EUR.

E4. Operating costs - costs accrued for transfer of LNG to the infrastructure networks onshore.

\section{Group of Technical Criteria (T):}

T1. Safety of gas supply - in case of disturbed natural gas supply, especially during the cold season, it is possible to suffer a great loss, especially if such situation persists until a way to supplement the stock of reserve fuel (usually oil products) is found.

T2. Duration of construction - time, during which the LNG terminal will be built.

T3. Interruption of LNG terminal activities - due to navigation restrictions (average number of days per year).

Having analysed the project report on the LNG terminal, a combined data matrix was made (Table 1), where numeric values of criteria are presented.

The weight coefficients for every group of criteria were determined according to the degree of importance of each one: social $15 \%$, environmental $30 \%$, economic $35 \%$ and technical $20 \%$ (the sum totals $100 \%$ ). Then, the weight coefficients for each criterion of each group of criteria were determined, depending on the degree of importance that each criterion has in the group. The sum of weight coefficients of each team was equal to 100\% (Rousis et al. 2008).

In Table 1, the individual weight coefficients for each criterion are presented. These were calculated by multiplying the weight coefficients of categories-groups by the corresponding weight coefficients of criteria in each group. The sum of weight coefficients of individual criteria equals $100 \%$. The determination of the criteria weight coefficients was based on: the experience in relative applications and the development plan of LNG import terminal.

\section{Multi-Criteria Solution of the Problem}

Three well-known Multi-Criteria Decision-Making (MCDM) methods were selected:

- Simple Additive Weighting (SAW);

- Complex Proportional Assessment (COPRAS);

- Technique for Order Preference by Similarity to Ideal Solution (TOPSIS).

SAW is the oldest, most widely known and practically used method. The idea of qualitative multi-criteria methods is well demonstrated by the SAW method (Hwang, Yoon 1981; Palevičius et al. 2013; Simanavičienè et al. 2012; Yazdani-Chamzini et al. 2013; Chen 2012).

In 1996, the researchers of Vilnius Gediminas Technical University (Zavadskas, Kaklauskas 1996) created a method of complex proportional evaluation COPRAS. It is used for multi-criteria evaluation of both maximizing and minimizing criteria values. COPRAS method

Table 1. The main matrix of natural gas terminal combined data

\begin{tabular}{|c|c|c|c|c|c|c|c|c|}
\hline \multirow{2}{*}{\multicolumn{3}{|c|}{ Criteria }} & \multirow{2}{*}{ Units } & \multicolumn{3}{|c|}{ Alternatives } & \multicolumn{2}{|c|}{ Weight } \\
\hline & & & & I & II & III & In group & Total \\
\hline \multicolumn{3}{|r|}{ Social } & & & & & \multicolumn{2}{|l|}{0.15} \\
\hline S1 & $\max$ & International relations & points & 6 & 10 & 3 & 0.40 & 0.060 \\
\hline S2 & $\max$ & Civil safety & points & 7 & 9 & 10 & 0.35 & 0.053 \\
\hline \multirow[t]{2}{*}{ S3 } & $\max$ & Psycho-emotional background & points & 3 & 5 & 10 & 0.25 & 0.038 \\
\hline & \multicolumn{2}{|r|}{ Environmental } & & & & & \multicolumn{2}{|l|}{0.30} \\
\hline A1 & $\max$ & Landscape & points & 7 & 7 & 10 & 0.35 & 0.105 \\
\hline $\mathrm{A} 2$ & $\max$ & Cultural heritage & points & 10 & 7 & 7 & 0.25 & 0.075 \\
\hline A3 & $\max$ & Biological diversity & points & 10 & 8 & 9 & 0.25 & 0.075 \\
\hline A4 & $\max$ & Environmental air & points & 9 & 10 & 10 & 0.10 & 0.030 \\
\hline \multirow[t]{2}{*}{ A5 } & $\max$ & Noise & points & 9 & 10 & 10 & 0.05 & 0.015 \\
\hline & \multicolumn{2}{|r|}{ Economic } & & & & & \multicolumn{2}{|l|}{0.35} \\
\hline E1 & $\max$ & Influence on Klaipeda Seaport expansion & points & 9 & 7 & 10 & 0.20 & 0.070 \\
\hline $\mathrm{E} 2$ & $\max$ & Land use & points & 10 & 7 & 8 & 0.15 & 0.053 \\
\hline E3 & $\min$ & Construction costs & $10^{6} \mathrm{EUR}$ & 87 & 250 & 250 & 0.40 & 0.140 \\
\hline \multirow[t]{2}{*}{$\mathrm{E} 4$} & $\min$ & Operating costs & $10^{6} \mathrm{EUR}$ & 15 & 19.5 & 21 & 0.25 & 0.088 \\
\hline & & Technical & & & & & 0.20 & \\
\hline $\mathrm{T} 1$ & $\max$ & Safety of gas supply & points & 10 & 6 & 6 & 0.35 & 0.070 \\
\hline $\mathrm{T} 2$ & $\min$ & Duration of construction & months & 18 & 30 & 31 & 0.45 & 0.090 \\
\hline T3 & $\min$ & Interruption of LNG terminal activities & days & 25 & 45 & 45 & 0.20 & 0.040 \\
\hline
\end{tabular}


is widely used for evaluation of complex processes by quantitative multi-criteria methods (Chatterjee et al. 2011; Bitarafan et al. 2012; Tavana et al. 2013; Fouladgar et al. 2012a; Kildienè et al. 2011; Tamošaitienè, Gaudutis 2013; Hashemkhani Zolfani et al. 2012; Nguyen et al. 2014; Mulliner et al. 2013; Podvezko 2011). This method assumes direct and proportional dependence of priority and utility degree of study alternatives on the system of indices adequately describing the alternatives as well as on values and significances of indices.

Method TOPSIS was developed by Hwang and Yoon (1981). The technique is based on the idea that the optimal alternative is the most similar to the ideal solution (being closest to it and at the longest distance from the negatively ideal solution). This method is known as TOPSIS (Staniūnas et al. 2013; Fouladgar et al. 2012b; Pinter, Pšunder 2013; Zavadskas et al. 2012, 2013; Paksoy et al. 2012; Baležentis et al. 2012).

The cumulative problems solution results are presented in Table 2. Calculations conducted using different MCDM method show that among the investigated three construction site alternatives for LPG terminal, Kiauless Nugara island is the best alternative.

Having performed calculations with the help of three methods (SAW, COPRAS and TOPSIS) it was determined that the best alternative to build the LNG terminal is the Kiaulès Nugara island.

Built on the Kiaules Nugara island, the LNG terminal would not be the first terminal built inside the territory of a seaport. A very good example is the LNG terminal Enagás, built in Barcelona. This LNG terminal was built in 1969. During the period since the terminal commenced its operation, there hasn't been a single accident. Close to the terminal, containers and chemical products are handled as well as Ro-Ro freight terminals operate. Currently, a capacity of Enagás terminal reaches $12 \cdot 10^{6} \mathrm{Nm}^{3}$ of gas per year (Enagás 2013). Infrastructural and environmental solutions of this seaport might be relevant to Klaipeda as well.

\section{Conclusions}

The problem of construction site selection for the LNG terminal should to be investigated and solved using the multiple criteria set. The research presents model of application of three different MCDM methods and aggregation of solution results. Having performed calculations in three methods, it was determined that the best alternative to build the LNG terminal is the Kiaules Nugara island. Based on a more in-depth analysis, several core advantages in favour of Kiaulès Nugara island were identified:
- the seaport area has all the infrastructure required for implementation and operation of the LNG terminal;

- construction of the LNG terminal in the seaport would reduce the impact of meteorological conditions on operations of the terminal;

- closest possible connection to the gas pipeline;

- fastest technological solution for building the LNG terminal.

\section{References}

Augutis, J.; Krikštolaitis, R.; Ušpuras, E. 2013. Lithuanian activities in energy security, in C. A. Brebbia (Eds.). Risk Analysis VIII: WIT Transactions on Information and Communication Technologies, 3-12.

Baležentis, A.; Baležentis, T.; Misiūnas, A. 2012. An integrated assessment of Lithuanian economic sectors based on financial ratios and fuzzy MCDM methods, Technological and Economic Development of Economy 18(1): 34-53. http://dx.doi.org/10.3846/20294913.2012.656151

Bitarafan, M.; Hashemkhani Zolfani, S.; Arefi, S. L.; Zavadskas, E. K. 2012. Evaluating the construction methods of cold-formed steel structures in reconstructing the areas damaged in natural crises, using the methods AHP and COPRAS-G, Archives of Civil and Mechanical Engineering 12(3): 360-367. http://dx.doi.org/10.1016/j.acme.2012.06.015

Chatterjee, P.; Athawale, V. M.; Chakraborty, S. 2011. Materials selection using complex proportional assessment and evaluation of mixed data methods, Materials \& Design 32(2): 851-860. http://dx.doi.org/10.1016/j.matdes.2010.07.010

Chen, T.-Y. 2012. Comparative analysis of SAW and TOPSIS based on interval-valued fuzzy sets: discussions on score functions and weight constraints, Expert Systems with Applications 39(2): 1848-1861.

http://dx.doi.org/10.1016/j.eswa.2011.08.065

Enagás. 2013. Enagás Company. Madrid, Spain. Available from Internet: http://www.enagas.es

Foss, M. M. 2006. Offshore LNG Receiving Terminals: a Briefing Paper from the Guide to Commercial Frameworks for LNG in North America. Center for Energy Economics (CEE), Bureau of Economic Geology, The University of Texas at Austin. 64 p. Available from Internet: http://www.beg.utexas. edu/energyecon/lng/documents/CEE_offshore_LNG.pdf

Fouladgar, M. M.; Yazdani-Chamzini, A.; Lashgari, A.; Zavadskas, E. K.; Turskis, Z. 2012a. Maintenance strategy selection using AHP and COPRAS under fuzzy environment, International Journal of Strategic Property Management 16(1): 85-104. http://dx.doi.org/10.3846/1648715X.2012.666657

Fouladgar, M. M.; Yazdani-Chamzini, A.; Zavadskas, E. K. 2012b. Risk evaluation of tunneling projects, Archives of Civil and Mechanical Engineering 12(1): 1-12. http://dx.doi.org/10.1016/j.acme.2012.03.008

Table 2. Ranking of alternatives

\begin{tabular}{|c|c|c|c|c|c|c|c|c|}
\hline \multirow{2}{*}{ LNG terminal location } & \multicolumn{2}{|c|}{ SAW } & \multicolumn{2}{|c|}{ COPRAS } & \multicolumn{2}{|c|}{ TOPSIS } & \multirow{2}{*}{ Sum of ranks } & \multirow{2}{*}{ Average rank } \\
\hline & $S_{i}$ & Rank & $Q_{i}$ & Rank & $C_{i}^{+}$ & Rank & & \\
\hline Kiaulès Nugara island & 0.891 & 1 & 0.949 & 1 & 0.626 & 1 & 3 & 1 \\
\hline Melnragė & 0.678 & 3 & 0.587 & 3 & 0.374 & 2 & 8 & 2.67 \\
\hline Butingè & 0.718 & 2 & 0.593 & 2 & 0.318 & 3 & 7 & 2.33 \\
\hline
\end{tabular}


Hashemkhani Zolfani, S.; Chen, I.-S.; Rezaeiniya, N.; Tamošaitienè, J. 2012. A hybrid MCDM model encompassing AHP and COPRAS-G methods for selecting company supplier in Iran, Technological and Economic Development of Economy 18(3): 529-543. http://dx.doi.org/10.1016/10.3846/20294913.2012.709472

Hwang, C.-L.; Yoon, K. 1981. Multiple Attribute Decision Making: Methods and Applications: a State-of-the-Art Survey. 1st edition. Springer. 259 p.

Jakštas, T. 2010. Ar Lisabonos sutartis turi įtakos Europos bendros energetikos politikos plètrai?, Politologija (4): 113-141.

Kildienè, S.; Kaklauskas, A.; Zavadskas, E. K. 2011. COPRAS based comparative analysis of the European Country management capabilities within the construction sector in the time of crisis, Journal of Business Economics and Management 12(2): 417-434.

http://dx.doi.org/10.3846/16111699.2011.575190

Lietuvos Respublikos teritorijos bendrasis planas. 2002. Lietuvos Respublikos Seimo 2002 m. spalio 29 d. nutarimas Nr. IX1154. Available from Internet: http://www3.lrs.lt/pls/inter2/ dokpaieska.showdoc_l?p_id=284909 (in Lithuanian).

LNG Terminal at Port of Rotterdam, The Netherland. 2013. Available from Internet: http://www.vopaklng.com

Ludescher, H.; Naess, J.; Bjerkeli, L. 2011. Detailed design of a gravity-based structure for Adriatic liquefied natural gas terminal, Structural Engineering International 21(1): 99-106. http://dx.doi.org/10.2749/101686611X12910257102712

Mulliner, E.; Smallbone, K.; Maliene, V. 2013. An assessment of sustainable housing affordability using a multiple criteria decision making method, Omega 41(2): 270-279. http://dx.doi.org/10.1016/j.omega.2012.05.002

NatGas.info. 2013. The Independent Natural Gas Information Site. Available from Internet: http://www.natgas.info

Nguyen, H.-T.; Dawal, S. Z.; Nukman, Y.; Aoyama, H. 2014. A hybrid approach for fuzzy multi-attribute decision making in machine tool selection with consideration of the interactions of attributes, Expert Systems with Applications 41(6): 3078-3090. http://dx.doi.org/10.1016/j.eswa.2013.10.039

Pajūrio žemyninès dalies tvarkymo specialusis planas. 2011. Lietuvos Respublikos aplinkos ministro $2011 \mathrm{~m}$. liepos $28 \mathrm{~d}$. isakymas Nr. D1-601 (in Lithuanian).

Palevičius, V.; Paliulis, G. M.; Venckauskaite, J.; Vengrys, B. 2013. Evaluation of the requirement for passenger car parking spaces using multi-criteria methods, Journal of Civil Engineering and Management 19(1): 49-58 http://dx.doi.org/10.3846/13923730.2012.727463

Paksoy, T.; Pehlivan, N. Y.; Kahraman, C. 2012. Organizational strategy development in distribution channel management using fuzzy AHP and hierarchical fuzzy TOPSIS, Expert Systems with Applications 39(3): 2822-2841. http://dx.doi.org/10.1016/j.eswa.2011.08.142

Pinter, U.; Pšunder, I. 2013. Evaluating construction project success with use of the M-TOPSIS method, Journal of Civil Engineering and Management 19(1): 16-23. http://dx.doi.org/10.3846/13923730.2012.734849

Podvezko, V. 2011. The comparative analysis of MCDA methods SAW and COPRAS, Inzinerine Ekonomika - Engineering Economics 22(2): 134-146.

http://dx.doi.org/10.5755/j01.ee.22.2.310

Rousis K.; Moustakas, K.; Malamis, K.; Papadopoulos, A.; Loizidou, M. 2008. Multi-criteria analysis for the determination of the best WEEE management scenario in Cyprus, Waste Management 28(10): 1941-1954.

http://dx.doi.org/10.1016/j.wasman.2007.12.001
SAIC. 2010. LNG Import Feasibility Study for Lithuania. Final Presentation (prepared for Lithuanian Ministry of Energy). Science Applications International Corporation (SAIC).

Simanavičienè, R.; Liaudanskienè, R.; Ustinovichius, L. 2012. A new synthesis method of structural, technological and safety decisions (SyMAD-3), Journal of Civil Engineering and Management 18(2): 265-276. http://dx.doi.org/10.3846/13923730.2012.666504

South Hook LNG Terminal. 2013. Available from Internet: http://www.southhooklng.co.uk

Staniūnas, M.; Medineckienė, M.; Zavadskas, E. K.; Kalibatas, D. 2013. To modernize or not: ecological-economical assessment of multi-dwelling houses modernization, Archives of Civil and Mechanical Engineering 13(1):88-98 http://dx.doi.org/10.1016/j.acme.2012.11.003

Sweco Lietuva. 2011. Suskystintu gamtiniu duju importo terminalo plètros planas. 11072-00-PP-AR (in Lithuanian).

Sweco Lietuva. 2012. Suskystintu gamtiniu duju terminalo, susijusios infrastruktūros ir dujotiekio statybos specialusis planas. 12005-00-STP-K.AR (in Lithuanian).

Sweden's First LNG Terminal at Nynäshamn. 2013. Available from Internet: http://www.the-linde-group.com

Tamošaitienè, J.; Gaudutis, E. 2013. Complex assessment of structural systems used for high-rise buildings, Journal of Civil Engineering and Management 19(2): 305-317. http://dx.doi.org/10.3846/13923730.2013.772071

Tarpžinybinès darbo grupés dèl suskystintu gamtiniu dujų terminalo statybos Lietuvoje ataskaita. 2010. Vilnius. Available from Internet: http://www.enmin.lt/lt/news/SGD_terminalo_ataskaita.pdf (in Lithuanian).

Tarvydas, D.; Gatautis, R. 2006. Liquefied natural gas in the world and Lithuanian perspective, Energetika (3): 94-101.

Tavana, M.; Momeni, E.; Rezaeiniya, N.; Mirhedayatian, S. M.; Rezaeiniya, H. 2013. A novel hybrid social media platform selection model using fuzzy ANP and COPRAS-G, Expert Systems with Applications 40(14): 5694-5702. http://dx.doi.org/10.1016/j.eswa.2013.05.015

Yazdani-Chamzini, A.; Fouladgar, M. M.; Zavadskas, E. K.; Haji Moini, S. H. 2013. Selecting the optimal renewable energy using multi criteria decision making, Journal of Business Economics and Management 14(5): 957-978. http://dx.doi.org/10.3846/16111699.2013.766257

Zavadskas, E. K.; Kaklauskas, A. 1996. Determination of an efficient contractor by using the new method of multicriteria assessment, in D. A. Langford, A. Retik (Eds.). International Symposium for The Organisation and Management of Construction: Shaping Theory and Practice, Vol. 2: Managing the Construction Project and Managing Risk, 94-104.

Zavadskas, E. K.; Sušinskas, S.; Daniūnas, A.; Turskis, Z.; Sivilevičius, H. 2012. Multiple criteria selection of pile-column construction technology, Journal of Civil Engineering and Management 18(6): 834-842. http://dx.doi.org/10.3846/13923730.2012.744537

Zavadskas, E. K.; Turskis, Z.; Volvačiovas, R.; Kildienè, S. 2013. Multi-criteria assessment model of technologies, Studies in Informatics and Control 22(4): 249-258. 